\title{
Isolation and genotyping of Clostridium perfringens and Clostridium difficile in Capuchin Monkeys (Sapajus spp.)
}

\author{
Rodrigo Otávio Silveira Silva ${ }^{1^{*}}$ Débora Rochelly Alves Ferreira ${ }^{2}$ \\ Plautino de Oliveira Laroquec ${ }^{3}$ Rafael Gariglio Clark Xavier ${ }^{1}$ \\ Francisco Carlos Faria Lobato ${ }^{1}$ Rinaldo Aparecido Mota ${ }^{2}$
}

${ }^{1}$ Escola de Veterinária, Universidade Federal de Minas Gerais (UFMG), Antônio Carlos Avenue, 6627, 31.270-901, Belo Horizonte, MG, Brasil. E-mail: rodrigo.otaviosilva@gmail.com. *Corresponding author.

${ }^{2}$ Departamento de Medicina Veterinária, Universidade Federal Rural de Pernambuco (UFRPE), Recife, PE, Brasil.

${ }^{3}$ Centro Nacional de Pesquisa e Conservação de Primatas Brasileiros, Instituto Chico Mendes de Conservação da Biodiversidade (ICMBio), Brasília, DF, Brasil.

\begin{abstract}
The importance of Clostridium perfringens and C. difficile for most wild animal species remains unclear. This study aimed to isolate and genotype $C$. perfringens and C. difficile in stool samples from free-living and captive capuchin monkeys (Sapajus flavius and Sapajus libidinosus) in Brazil. Ten free-living S. flavius and 14 captive S. libidinosus were sampled for this study. To isolate C. difficile, stool samples were inoculated on plates containing cycloserine-cefoxitin fructose agar supplemented with horse blood and sodium taurocholate. Two different protocols for C. perfringens isolation were tested: direct plating onto selective agar and enrichment in brain heart infusion (BHI) broth followed by plating onto selective agar. C. difficile was not detected in the present study. The results were identical for both protocols tested for isolation of C. perfringens. Four samples (16.7\%) were positive for C. perfringens type A, including one sample from a free-living animal (4.2\%) and three from captive animals (12.5\%), meaning there was no significant difference between these two groups. C. perfringens isolates were negative for all additional virulence factors evaluated, including enterotoxin encoding-gene (cpe) and beta-2 encoding-gene (cpb2). These results suggested that C. perfringens type A is found in the microbiota of capuchin monkeys, although it is less frequent than previously reported in domestic animals.
\end{abstract}

Key words: New World Primates (NWP), enterocolitis, Sapajus libidinosus, Sapajus flavius.

Isolamento e genotipagem de Clostridium perfringens and Clostridium difficile em macacos-prego (Sapajus spp.)

RESUMO: A importância de Clostridium perfringens e C. difficile para a maioria das espécies silvestres ainda não está clara. O objetivo do presente estudo foi isolar e genotipar C. perfringens e C. difficile em amostras de fezes de macacos-prego (Sapajus flavius e Sapajus libidinosus) de vida livre e criados em cativeiros no Brasil. Dez S. flavius de vida livre e 14 S. libidinosus de cativeiro foram incluidos no presente estudo. Para isolamento de C. difficile, as amostras de fezes foram inoculadas em agar cicloserina-cefoxitina frutose, suplementado com sangue e taurocolato de sódico. Para isolamento de C. perfringens, foram testados dois protocolos: plaqueamento direto em ágar seletivo e enriquecimento em caldo seguido de plaqueamento em ágar seletivo. C difficile não foi detectado no presente estudo. Os resultados foram idênticos para ambos os protocolos testados para isolamento de C. perfringens, resultando em quatro animais $(16,7 \%)$ positivos para C. perfringens tipo A. Destes, uma amostra era de um animal de vida livre (4,2\%) e três de animais de cativeiro (12,5\%), não havendo diferença entre esses dois grupos. Os isolados de C. perfringens foram negativos para todos os fatores de virulência adicionais avaliados, incluindo o gene codificador de enterotoxina (cpe) e o gene codificador beta-2 (cpb2). O presente estudo sugere C. perfringens tipo A como parte da microbiota de macacos-prego, embora esse agente seja menos frequente como comensal, do que relatado anteriormente, em animais domésticos.

Palavras-chave: New World Primates (NWP), enterocolite, Sapajus libidinosus, Sapajus flavius.

Non-human primates (NHP) are known as natural reservoirs of several human pathogens and can serve as natural sentinels for investigation of epizootics and endemic diseases of public health importance (FERREIRA et al., 2015; SVOBODA et al., 2016). Among NHP, capuchin monkeys (Sapajus sp.) are widely distributed throughout tropical and subtropical
South America, including Brazil. Recently, a new species called Sapajus flavius was rediscovered in Brazil (BACALHAO et al., 2016), but it is already listed as an endangered species (BRAZIL, 2014). Despite the known importance of NHP as reservoirs of human pathogens, there are few studies focusing specifically on capuchin monkeys (BATISTA et al., 2013; ROCHA et al., 2015). 
Clostridium difficile is a major nosocomial pathogen in humans and causes diarrhea and enterocolitis in domestic animals (RODRIGUEZPALACIOS et al., 2013). There are few studies about this enteropathogen in wild animals, but confirmed cases of $C$. difficile infection (CDI) have been reported in some species (BOJESEN et al., 2006; SILVA et al., 2013). In addition, recent studies have shown that wild animals can harbor $C$. difficile strains genetically similar to those responsible for CDI in humans (JARDINE et al., 2013; HIMSWORTH et al., 2014; SILVA et al., 2014; ANDRÉS-LASHERAS et al., 2017). Thus, because some studies have hypothesized $C$. difficile to be a zoonotic pathogen (HENSGENS et al., 2012), there is a need to clarify its epidemiology and to study the role of this bacterium in captive and free-living wild animals. So far, there have been no studies evaluating the fecal shedding of $C$. difficile by NHP.

Strains of $C$. perfringens are conventionally classified into five toxigenic types (A-E) based on their capacity to produce one or more of the four major toxins (alpha, beta, epsilon and iota) (UZAL et al., 2014). Furthermore, C. perfringens can produce additional virulence factors such as enterotoxin, which is responsible for diarrhea in humans (LINDSTRÖM et al., 2011), necrotic enteritis toxin B-like (NetB), which is responsible for necrotic enteritis in broiler chickens (KEYBURN et al., 2008), and NetF, which is associated with acute diarrhea in dogs and foals (GOHARI et al., 2015; DINIZ et al., 2016). Despite its importance as an enteropathogen, $C$. perfringens is commonly reported in the enteric microbiota of healthy animals, thus complicating the laboratory diagnosis of infections caused by this microorganism (SILVA et al., 2015). In wild animals, despite some case reports, the importance of $C$. perfringens remains unclear (SILVA et al., 2015). Specifically, in NHP species, the most common genotypes and the importance of additional virulence factors of $C$. perfringens are largely unknown.

Isolating and screening for virulence factor genes could contribute to the understanding of $C$. difficile and $C$. perfringens transmission patterns, risk factors and epidemiology (SILVA et al., 2014; SILVA et al., 2016). Thus, this study aimed to isolate and genotype $C$. difficile and $C$. perfringens strains from free-living and captive capuchin monkeys (Sapajus sp.) in Brazil.

From May 2015 to January 2016, Sapajus flavius (ten free-living) and Sapajus libidinosus (14 in captivity) were sampled for this study. Free-living animals were trapped with a tomahawk-like trap in a small conservation area called "Mata do Corrego do Inferno" in Pernambuco State. (07³0'47.7”S,
34 $\left.58^{\circ} 33.2^{\prime \prime} \mathrm{W}\right)$. Stool samples were collected after natural defecation and stored at $-20^{\circ} \mathrm{C}$ until testing. Each individual received a microchip to prevent multiple samples from being collected from the same animal. Captive animals were sampled at a rescue agency for wildlife animals (Centro de Triagem de Animais Silvestres from Pernambuco State - CETAS/ PE). Stool samples were collected directly from cages just after defecation, avoiding parts that had contacted the floor, and were stored at $-20^{\circ} \mathrm{C}$ until testing. The present research was authorized by ICMBio/SISBIO (47672-1/2015) and the Ethical Committee from the Universidade Federal de Campina Grande (Protocol number 0048/18032015).

The isolation of $C$. difficile was based on a previously reported protocol (SILVA et al., 2014a). Briefly, stool samples were inoculated on plates containing cycloserine-cefoxitin fructose agar supplemented with $7 \%$ horse blood and $0.1 \%$ sodium taurocholate (Sigma-Aldrich Co., USA). After anaerobic incubation at $37^{\circ} \mathrm{C}$ for 72 hours, all colonies were subjected to thermal DNA extraction (BAUMS et al., 2014), and then, multiplex PCR was used to detect a housekeeping gene (tpi), toxins A $(t c d A)$ and $\mathrm{B}(t c d B)$ and a binary toxin gene $(c d t B)$ as previously described (SILVA et al., 2011).

The isolation of $C$. perfringens was also based on a previously reported protocol (SILVA et al., 2016). Approximately $0.08-0.12 \mathrm{~g}$ of feces was serially diluted by factors of 10 , ranging from $10^{-1}$ to $10^{-3}$. Aliquots of $10 \mu \mathrm{l}$ of each dilution were plated on sulfite polymyxin sulfadiazine agar (SPS, Difco Laboratories, USA) and were anaerobically incubated at $37^{\circ} \mathrm{C}$ for 24 hours. After incubation, at least three characteristic colonies from each dilution were subjected to thermal DNA extraction (BAUMS et al., 2014), and then, a previously described PCR protocol (VIEIRA et al., 2008) was used to detect genes encoding the major $C$. perfringens toxins (alpha, beta, epsilon and iota), beta2 toxin (cpb2) and enterotoxin (cpe). For detecting the NetB-, NetE-, NetF and NetG-encoding genes (netB, $n e t E$, net $F$ and net $G$, respectively), PCR protocols described by KEYBURN et al. (2008) and GOHARI et al. (2015) were applied. Thawed aliquots of stool samples positive for $C$. perfringens $c p e^{+}$strains were subjected to enterotoxin detection with a commercial EIA kit (RIDASCREEN ${ }^{\circledR}$ Clostridium perfringens Enterotoxin - R-Biopharm, Germany). Fisher's exact test was used to evaluate associations between variables. Significance was set at a P value of $<0.05$ (STATA, College Station, Texas, EUA).

Bacterial infections associated with NHPs constitute the more common zoonoses and include 
gastrointestinal infections caused by several enteric pathogens (ADAMS et al., 1995). Despite the known importance of $C$. perfringens and $C$. difficile for animals and their possible roles as zoonotic pathogens, there are few studies evaluating these agents in NHP species. In the present study, $C$. difficile was not detected. So far, there is only one reported outbreak of $C$. difficile infection in NHP. In that report, five individuals from a colony of cottontop tamarins (Saguinus oedipus) died spontaneously after antibiotic therapy for infectious diarrhea associated with Campylobacter spp. (ROLLAND et al., 1997). C. difficile has been reported in few other wild species, and it seems to be more common in synanthropic rodents and in captive animals under antibiotic therapy (SILVA et al., 2013; JARDINE et al., 2013; RODRIGUEZ-PALACIOS et al., 2013; HIMSWORTH et al., 2014; SILVA et al., 2014a; SILVA et al., 2014b). As this was not the case in the present study, the absence of $C$. difficile in the sampled animals was not a surprise.

Four capuchin monkeys $(16.7 \%)$ were positive for $C$. perfringens type $\mathrm{A}$ in the present research. Although, $C$. perfringens is commonly isolated from up to $90 \%$ of healthy individuals in domestic species, its prevalence seems to vary widely among wild animals (SILVA et al., 2015; MILTON et al., 2017). In addition, there have been few studies about $C$. perfringens in monkeys and none specifically with Sapajus sp., making comparisons difficult. The reported frequencies of $C$. perfringens in these previous studies with NHP vary from $0 \%$ in blackeared marmosets (Callithrix penicillata) to $80 \%$ in captive chimpanzees (FUJITA \& KAGEYAMA, 2006; MAFRUZA et al., 2012; MTSHALI et al., 2012). It is also interesting to note that among the four isolates obtained, one sample was from a free-living animal $(4.2 \%)$, and three were from captive monkeys (12.5\%), meaning there was no significant difference between these two groups $(p=0.6146)$. These results are in contrast with a previous study with chimpanzees, which reported that captive individuals were more likely to be positive for $C$. perfringens (FUJITA \& KAGEYAMA et al., 2006). These previous reports and the present study suggested differences in the frequency of $C$. perfringens among different NHP species, implying that broad studies with each species, including both free-living and captive individuals, are necessary to clarify the roles of this agent as a commensal in NHP.

All four isolates obtained in the present study were negative for all additional virulence factors tested, including beta-2 toxin encoding-gene (cpb2), already reported in other wild animals, and enterotoxin- encoding gene (cpe), an important virulence factor for $C$. perfringens associated with disease in humans (GORMLEY et al., 2011; SILVA et al., 2015; MILTON et al., 2017). This is the first study to genotype and evaluate these common additional virulence factors in C. perfringens isolated from NHPs, so it is impossible to compare these findings to those from other primate species. Regardless, our results suggested that these additional virulence factors are less common in capuchin monkeys than in other wild animals including ruminants, canids, felids and birds (SILVA et al., 2014; SILVA et al., 2015; MILTON et al., 2017).

It is also important to note that the results were identical for both isolation protocols tested. This is similar to results previously reported in dogs (GOLDSTEIN et al., 2012) but different from a study with South American coatis (Nasua nasua), which reported that the colonization rate of $C$. perfringens in this species would be underestimated if only direct plating onto selective agar was used (SILVA et al., 2016). Thus, the present study suggested that simple direct plating on selective agar can be applied for further studies with Sapajus spp. Finally, the present study suggests that $C$. perfringens type $\mathrm{A}$ is part of the microbiota of capuchin monkeys, although it is less frequent than previously reported in domestic animals.

\section{ACKNOWLEDGMENTS}

This research was supported by funds from Coordenação de Aperfeiçoamento de Pessoal de Nível Superior (CAPES), Conselho Nacional de Desenvolvimento Científico e Tecnológico (CNPq), Pró-reitoria de Pesquisa da Universidade Federal de Minas Gerais (PRPq-UFMG) and Fundação de Apoio a Universidade Federal de Alfenas (FACEPE) (scholarship DCR $-0032-05.05 / 12$ and project APQ - 2112-5.05/12. CPB/ICMBio, Centro de Triagem de Animais Silvestres de Pernambuco (CETAS) / Agência Estadual de Meio Ambiente (CPRH) and Parque estadual Dois Irmãos are acknowledged for contribution.

\section{CONFLICT OF INTEREST}

The authors declare that they have no conflicts of interest.

\section{REFERENCES}

ADAMS, S. et al. Biosafety. In: BENNET B.T. et al. Non-human primates in biomedical research - Biology and managemet. New York, NY: Academic, 1995. p.375-420. Available from: $<$ http://www.sciencedirect. com/science/article/pii/B9780120886616500223>. Accessed: out. 27, 2017. doi: doi.org/10.1016/B978-012088661-6/50022-3.

ANDRÉS-LASHERAS, S. et al. Presence of Clostridium difficile in pig fecal samples and wild animal species associated with pig farms. J Appl Microbiol, v.122, n.2, p.462-472, 2017. Available from: $<$ http://onlinelibrary.wiley.com/doi/10.1111/jam.13343/abstract $>$. Accessed: out. 27, 2017. doi:10.1111/jam.13343. 
BACALHAO, M.B.M. et al. Morphological description of two species of Sapajus found in Paraíba: S. libidinosus and the newly discovered and endangered S. flavius. Pesq Vet Bras, v.36, n.4, p.317-321, 2016. Available from: $<$ http://dx.doi.org/10.1590/S0100-736X2016000400011 >. Accessed: out. 27, 2017. doi: 10.1590/S0100-736X2016000400011.

BAUMS C.G. et al. Diagnostic multiplex PCR for toxin genotyping of Clostridium perfringens isolates. Vet Microbiol, v.100, p.11-16, 2004. Available from: <https://www.ncbi.nlm.nih.gov/pubmed/15135508>. Accessed: out. 27, 2017. doi: 10.1016/S0378-1135(03)00126-3.

BOJESEN, A.M. et al. Fatal enterocolitis in Asian elephants (Elephas maximus) caused by Clostridium difficile. Vet Microbiol, v.116, n.4, p.329-335, 2006. Available from: <https://www.ncbi.nlm.nih. gov/pubmed/16737787>. Accessed: out. 27, 2017. doi: 10.1016/j. vetmic.2006.04.025

BRAZIL. Ministry of the Environment. 2014. Ordinance $N^{\circ} 444$. Recognized species of Brazilian fauna threatened with extinction those contained in the "National Official Species of Endangered Fauna”. Diário Oficial da União, 18/12/2014, Seção 01, Pág. 121.

DINIZ, A.N. et al. Clostridium perfringens type A netF and netE positive and Clostridium difficile co-infection in two adult dogs. Anaerobe, v.38, p.94-96, 2016. Available from: <https://www.ncbi. nlm.nih.gov/pubmed/26762654>. Accessed: out. 27, 2017. doi: 10.1016/j.anaerobe.2015.12.013.

FERREIRA, D.R.A. et al. Risk factors associated with Toxoplasma gondii Infection in captive Sapajus spp. Am J Primatol, v.77, p.558562, 2015. Available from: $<$ http://onlinelibrary.wiley.com/doi/10.1002/ ajp.22377/pdf>. Accessed: out. 27, 2017. doi: 10.1002/ajp.22377.

FUJITA, S. et al. Polymerase chain reaction detection of Clostridium perfringens in feces from captive and wild chimpanzees (Pan troglodytes). J Med Primatol, v.36, n.1, p.25-32, 2007. Available from: $<\mathrm{http} / / /$ onlinelibrary.wiley.com/doi/10.1111/j.1600-0684.2006.00191.x/ pdf > . Accessed: out. 27, 2017. doi: 10.1111/j.1600-0684.2006.00191.x.

BATISTA, P.M. et al. Detection of arboviruses of public health interest in free-living New World primates (Sapajus spp.; Alouatta caraya) captured in Mato Grosso do Sul, Brazil. Rev Soc Bras Med Trop, v.46, n.6, p.684-690, 2013. Available from: <http://www.scielo.br/ scielo.php?script $=$ sci arttext\&pid $=$ S0037-86822013000600684 $>$. Accessed: out. 27, 2017. doi: 10.1590/0037-8682-0181-2013.

GORMLEY, F.J. et al. A 17-year review of foodborne outbreaks: describing the continuing decline in England and Wales (1992-2008). Epidemiol Infect, v.139, n.5, p.688-699, 2011. Available from: $<$ https://www.ncbi.nlm.nih.gov/pubmed/20696086>. Accessed: out. 27, 2017. doi: 10.1017/S0950268810001858.

ROCHA, T.C. et al. Evaluation of arboviruses of public health interest in free-living non-human primates (Alouatta spp., Callithrix spp., Sapajus spp.) in Brazil. Rev Soc Bras Med Trop, v.48, p.143-148, 2015. Available from: $<\mathrm{http} / /$ www.scielo.br/scielo.php?script=sci_ar ttext\&pid=S0037-86822015000200143>. Accessed: out. 27, 2017. doi: 10.1590/0037-8682-0024-2015.

MILTON,A.A.P. et al. Prevalence and molecular typing of Clostridium perfringens in captive wildlife in India. Anaerobe, v.44, p.5557, 2017. Available from: <https://www.ncbi.nlm.nih.gov/pubmed/28159707>. Accessed: out. 27, 2017. doi: 10.1016/j.anaerobe.2017.01.011Get.

MTSHALI, K. et al. Detection of Salmonella, Clostridium perfringens and Escherichia coli from fecal samples of captive animals at the
National Zoological Gardens of South Africa. African J Microbiol Res, v.6, p.3662-3666, 2012. Available from: $<$ http://www.academicjournals. org/journal/AJMR/article-abstract/9654D7E29931>. Accessed: out. 27, 2017. doi: 10.5897/AJMR12.107.

GOHARI, I.M. et al. A novel pore-forming toxin in type A Clostridium perfringens is associated with both fatal canine hemorrhagic gastroenteritis and fatal foal necrotizing enterocolitis. PLoS ONE, v.10, n.4, p.1-27, 2015. Available from: <https://www.ncbi.nlm.nih. gov/pubmed/25853427>. Accessed: out. 27, 2017. doi: 10.1371/ journal.pone. 0122684 .

GOLDSTEIN, M.R. et al. Detection and characterization of Clostridium perfringens in the feces of healthy and diarrheic dogs. Can J Vet Res, v.76, p.161-165, 2012. Available from: <https://www.ncbi.nlm.nih.gov/ pmc/articles/PMC3384277>. Accessed: out. 27, 2017.

HENSGENS, M.P. et al. European Society of Clinical Microbiology and Infectious Diseases Study Group for Clostridium difficile (ESGCD). Clostridium difficile infection in the community: a zoonotic disease? Clin Microbiol Infect, v.18, n.7, p.635-645, 2012. Available from: <https://www.ncbi.nlm.nih.gov/pubmed/22536816>. Accessed: out. 27, 2017. doi: dx.doi.org/10.1111/j.1469-0691.2012.03853.x.

HIMSWORTH, C.G. et al. Carriage of Clostridium difficile by wild urban Norway rats (Rattus norvegicus) and black rats (Rattus rattus). Appl Environ Microbiol, v.80, n.4, p.1299-1305, 2014. Available from: $<$ https:// www.ncbi.nlm.nih.gov/pmc/articles/PMC3911036/>. Accessed: out. 27, 2017. doi: 10.1128/AEM.03609-13.

JARDINE, C.M. et al. Detection of Clostridium difficile in small and medium-sized wild Mammals in Southern Ontario, Canada. J Wildl Dis, v.49, n.2, p.418-421, 2013. Available from: <https://www.ncbi.nlm.nih.gov/ pubmed/23568920>. Accessed: out. 27, 2017. doi: 0.7589/2012-04-120.

KEYBURN, A.L. et al. NetB, a new toxin that is associated with avian necrotic enteritis caused by Clostridium perfringens. PLoS Pathog, v.4, n.2, p.e26, 2008. Available from: <https://www.ncbi.nlm.nih.gov/ pmc/articles/PMC2233674/>. Accessed: out. 27, 2017. doi: 10.1371/ journal.ppat.0040026.

LINDSTRÖM, M. et al. Novel insights into the epidemiology of Clostridium perfringens type A food poisoning. Food Microbiol, v.28, n.2, p.192-198, 2011. Available from: <https://www.ncbi.nlm. nih.gov/pubmed/21315973>. Accessed: out. 27, 2017. doi: 10.1016/j. fm.2010.03.020.

MAFRUZA, S. et al. Characterization of Clostridium perfringens isolated from mammals and birds from Guwahati city, India. J Venom Anim Toxins incl Trop Dis, v.18, n.1, p.83-87, 2012. Available from: $<$ http://www.scielo. br/scielo.php?pid=S1678-91992012000100010\&script=sci_abstract $>$. Accessed: out. 27, 2017. doi: 10.1590/S1678-91992012000100010.

RODRIGUEZ-PALACIOS, A. et al. Clostridium difficile in foods and animals: history and measures to reduce exposure. Anim Health Res Rev, v.14, n.1, p.11-29, 2013. Available from: < https://www.ncbi.nlm. nih.gov/pubmed/23324529>. Accessed: out. 27, 2017. doi: 10.1017/ S1466252312000229.

ROLLAND, R.M. et al. Five spontaneous deaths associated with Clostridium difficile in a Colony of Cotton-Top Tamarins (Saguinus oedipus). Lab An Sci, v.47, p.472-476, 1997. Available from: <https:// www.ncbi.nlm.nih.gov/pubmed/9355088>. Accessed: out. 27, 2017.

SILVA, R.O. et al. Carriage of Clostridium difficile in free-living South American coati(Nasuanasua) in Brazil. Anaerobe, v.30, p.99-101,2014a. 
Available from: <https://www.ncbi.nlm.nih.gov/pubmed/25263534>. Accessed: out. 27, 2017. doi: 10.1016/j.anaerobe.2014.09.012.

SILVA, R.O. et al. Clostridium difficile and Clostridium perfringens from wild carnivore species in Brazil. Anaerobe, v.28, p.207-211, 2014b. Available from: <https://www.ncbi.nlm.nih.gov/pubmed/24979683>. Accessed: out. 27, 2017. doi: 10.1016/j.anaerobe.2014.06.012.

SILVA, R.O. et al. Clostridium difficile-associated diarrhea in an ocelot (Leopardus pardalis). Anaerobe, v.20, p.82-84, 2013. Available from: $<$ https://www.ncbi.nlm.nih.gov/pubmed/23467074>. Accessed: out. $27,2017$.

SILVA, R.O. et al. Clostridium perfringens: a review of enteric diseases in dogs, cats and wild animals. Anaerobe, v.33, p.14-17, 2015 Available from: <https://www.ncbi.nlm.nih.gov/pubmed/25644183>. Accessed: out. 27, 2017. doi: 10.1016/j.anaerobe.2014.06.012.

SILVA, R.O. et al. Detection of enterotoxin A and cytotoxin B, and isolation of Clostridium difficile in piglets in Minas Gerais, Brazil. Ciência Rural, v.41, p.1130-1135, 2011. Available from: <http://www.scielo. br/scielo.php?script $=$ sci arttext\&pid $=\mathrm{S} 0103-84782011000800021>$. Accessed: out. 27, 2017. doi: 10.1590/S0103-84782011005000100.
SVOBODA, W.K. et al. Serological evidence for Saint Louis encephalitis virus in free-ranging New World monkeys and horses within the upper Paraná River basin region, Southern Brazil. Rev Soc Bras Med Trop, v.47, p.280-286, 2014. Available from: <http://www.scielo.br/scielo.php?script=sci_artt ext\&pid $=$ S0037-86822014000300280 >. Accessed: out. 27, 2017. doi: 10.1590/0037-8682-0083-2014.

SILVA, R.O. et al. Isolation and genotyping of Clostridium perfringens from free-living South American coati (Nasua nasua). J Zoo Wildl Med, v.47, n.1, p.333-336, 2016. Available from: <https://www. ncbi.nlm.nih.gov/pubmed/27010297>. Accessed: out. 27, 2017. doi: 10.1638/2014-0189.1.

UZAL, F.A. et al. Towards an understanding of the role of Clostridium perfringens toxins in human and animal disease. Future Microbiol, v.9, n.3, p.361-377, 2014. Available from: <https://www.ncbi.nlm. nih.gov/pmc/articles/PMC4155746/>. Accessed: out. 27, 2017. doi: $10.2217 / \mathrm{fmb} .13 .168$

VIEIRA, A.A.S. et al. Genotyping of Clostridium perfringens isolated from diarrheic piglets. Arq Instit Biol, v.75, p.513-516, 2008. Accessed: out. 27, 2017. 